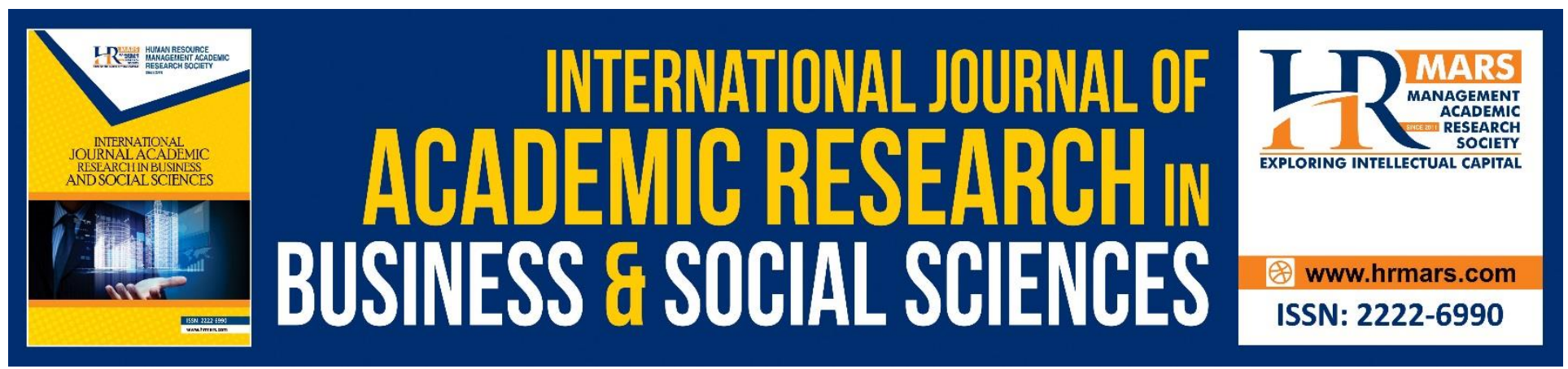

\title{
Human Resource Capability and Competitive Advantage of Sugar Companies in Western Kenya
}

\author{
Richard Misigo Imbambi, Leon Awiti, Ng'ong'a E. Aketch
}

To Link this Article: http://dx.doi.org/10.6007/IJARBSS/v9-i5/5852

DOI: $10.6007 /$ IJARBSS/v9-i5/5852

Received: 02 March 2019, Revised: 27 April 2019, Accepted: 1 May 2019

Published Online: 28 May 2019

In-Text Citation: (Imbambi, Awiti, \& Aketch, 2019)

To Cite this Article: Imbambi, R. M., Awiti, L., \& Aketch, N. E. (2019). Human Resource Capability and Competitive Advantage of Sugar Companies in Western Kenya. International Journal of Academic Research Business and Social Sciences, 9(5), 232-250.

Copyright: (C) 2019 The Author(s)

Published by Human Resource Management Academic Research Society (www.hrmars.com)

This article is published under the Creative Commons Attribution (CC BY 4.0) license. Anyone may reproduce, distribute, translate and create derivative works of this article (for both commercial and non-commercial purposes), subject to full attribution to the original publication and authors. The full terms of this license may be seen

at: http://creativecommons.org/licences/by/4.0/legalcode

Vol. 9, No. 5, 2019, Pg. 232 - 250

http://hrmars.com/index.php/pages/detail/IJARBSS

JOURNAL HOMEPAGE

Full Terms \& Conditions of access and use can be found at http://hrmars.com/index.php/pages/detail/publication-ethics 


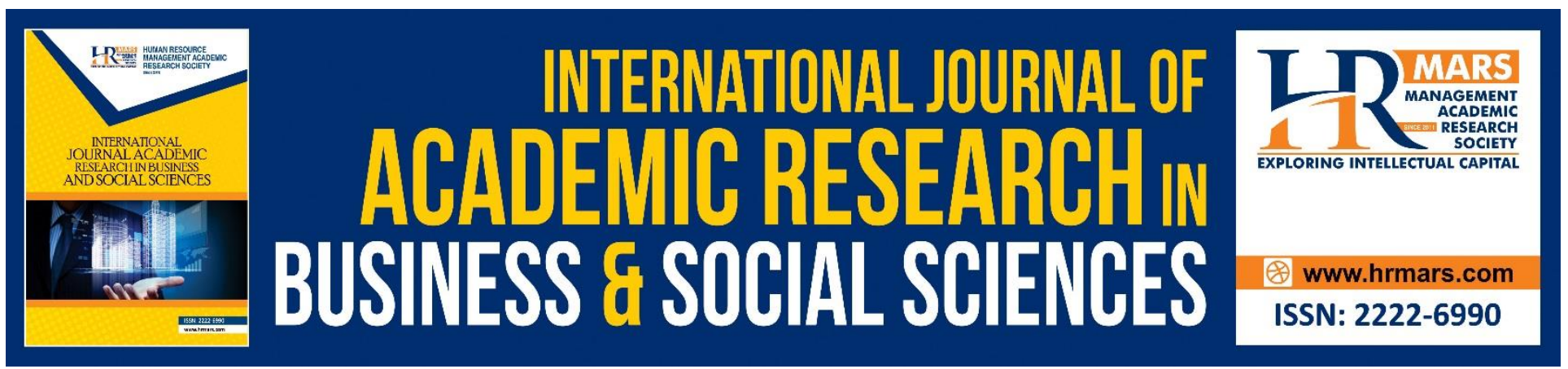

\title{
Human Resource Capability and Competitive Advantage of Sugar Companies in Western Kenya
}

Richard Misigo Imbambi, Ph.D.

Email: rmimbambi@yahoo.com

\author{
Leon Awiti, Ph.D. \\ Monitoring, Research, Evaluation and Learning Practitioner, Kenya \\ Email: awitileon@gmail.com
}

Ng'ong'a E. Aketch, Ph.D

Email: aketchngonga@yahoo.com

\begin{abstract}
The sugar industry contributes about 15 percent to the Kenya's agricultural GDP and supports an estimated 25 percent of the country's population. The objective of the study was to assess the influence of human resource capability in the context of strategic capability on competitive advantage of sugar companies in Western Kenya The target population was composed of six sugar companies; the respondents were 727 managers and the sample size consisted of 88 respondents with a response rate of $73 \%$. The primary data was collected using a questionnaire pretested for validity and reliability. Descriptive and inferential statistics were used to analyze the data. The logit results showed that companies that had a strong human resource capability were 1.012 times more likely to be competitive compared to those that had a weak human resource capability; correlation result was a weak positive statistically insignificant correlation between human resource capability and competitive advantage $(r=0.003)$ and hypothesis result showed that there was no statistically significant relationship between human resource capability and competitive advantage of sugar companies in Western Kenya. It was concluded that companies that had strong human resource capability were more likely to enjoy competitive advantage compared to those that had weak human resource capability. Competitive advantage of the sugar companies in Western Kenya is positively influenced by the human resource capability. It was recommended that the sugar industry should pay keen attention to how human resource capabilities are placed and utilized. If observed, the competitive advantage would be enhanced which would then lead to better performance of the sector.
\end{abstract}


INTERNATIONAL JOURNAL OF ACADEMIC RESEARCH IN BUSINESS AND SOCIAL SCIENCES Vol. 9, No. 5, May, 2019, E-ISSN: 2222-6990 ㄷ 2019 HRMARS

Keywords: Competitive Advantage, Human resource capability, Dynamic Capability, Strategic Capabilities

\section{Background to the Study}

How firms achieve and sustain competitive advantage is the most fundamental question in the field of strategic management (Rumelt, Schendel \& Teece, 1994). Effective strategic management requires an understanding of organizational resources and competencies as well as how each contributes to the formation of organizational strengths and ultimately to the development of a competitive advantage (Duncan, Gintei \& Swayne, 1998). Competitive advantage is often a single key element that gives an edge to a business beyond what the competition has or does. Top managers spend an inordinate amount of time analyzing, selecting, acquiring, or developing the necessary resources to enable their firm to gain competitive advantage. The source of sustained competitive advantage is the larger pool of human capital that constitutes the entire organization because they meet the criteria of being valuable, rare, inimitable and non-substitutable (Wright, McMahan \& McWilliams, 1993; Chuang, Liu \& Chen, 2014).

Argote and Ingram (2000) found out that knowledge embedded in the interactions of people, tools, and tasks provides a basis for competitive advantage in firms. Organizations are increasingly spending more money annually on training with the belief that it will give them a competitive advantage in the local and global market (Edralin, 2004). Batool and Batool (2012) research found a positive relation between training and development and competitive advantage. Faugoo (2009) empirical outcomes stressed that companies cope with the challenges posed by globalization, through the use of the RBV perspective, which regards employee skills, knowledge and experience as a source of competitive advantage through the use of Human Resource Capabilities. Zoubi (2012) found out that leadership competences had a statistically significant impact on competitive advantage. A study by Moorthy, Tan, Choo, Wei, Ping, and Leong (2012) showed that there is a significant negative relationship between inappropriate human resource management (HRM) and the firm performance.

Employees are the backbone of any business success and therefore, they need to be motivated and maintained in organization at all cost to aid the organization to be globally competitive in terms of providing quality products and services to the society (Ongori, 2007). Bula (2012) found out that labour turnover was widespread in the Kenya sugar industry. Plessis, Beaver, and Nel (2006) concluded that to achieve competitive advantage, organizations need to link Human Resource competencies to business strategy, be sensitive to internal and external change and the needs of the diverse workforce.

The development of the sugar industry in Kenya is inextricably linked to the history of Asian Agricultural Settlement in the country who were used by the British to build the railway line from Mombasa to Uganda (Wanyande, 2001). "Sugarcane as a crop was introduced in Kenya in 1902. The first sugarcane factory was set up at Miwani near Kisumu in 1922 and later at Ramisi in the coast province in 1927. The Government of Kenya has been widely involved in the expansion of sugar production through investments in sugarcane growing schemes and factories" (Odek, Kegode, \& Ochola 2003).

The Kenya Sugar industry is for self-reliance with respect to domestic demand, rather than as a major export cash crop (Kaumbutho, Awiti, \& Some, 1991). The sugar industry plays a significant role in 
INTERNATIONAL JOURNAL OF ACADEMIC RESEARCH IN BUSINESS AND SOCIAL SCIENCES Vol. 9, No. 5, May, 2019, E-ISSN: 2222-6990 @ 2019 HRMARS

Kenya's rural economy, contributing about 15 percent to the country's agricultural GDP (KSI, 2009). Smallholder farmers supply over 92 percent of the sugarcane processed by sugar companies, while the remainder is supplied by factory-owned nucleus estates (KSI, 2009; KSB, 2010). An estimated 25 percent of the country's population depends directly or indirectly on the sugar industry for their livelihood.

\section{Statement of the Problem}

Barney (1991) argues that determinants or sources of competitive advantage of a firm are resources which are rare, valuable, inability to be imitated, and inability to be substituted. One of these resources include the human capital, several authors have researched on the importance of training and development, leadership and labour turnover in achieving competitive advantage. The source of sustained competitive advantage is the human capital that constitutes the entire organization (Wright, McMahan \& McWilliams, 1993; Chuang, Liu \& Chen, 2014). Batool and Batool (2012) research found a positive relation between training and development and competitive advantage. Zoubi (2012) found out that leadership competences had a statistically significant impact on competitive advantage. On the Kenyan side Bula (2012) found out that labour turnover frustrates and impacts negatively on sugar firm performance in Kenya.

Several authors in Kenya have written about the strategic issues facing the sugar industry in Kenya but there is limited local empirical researches linking these problems to the influence of Human Resource capabilities on competitive advantage of the Kenya sugar industry. Therefore, there is a gap which this study filled by assessing the influence of human resource capability on competitive advantage of sugar companies in western Kenya.

\section{Objective of the Study}

To assess the influence of human resource capability in the context of strategic capability on competitive advantage of sugar companies in Western Kenya.

\section{Research Hypothesis}

$\mathbf{H}_{\mathbf{0}}$ : There is no statistically significant relationship between human resource capability and competitive advantage of sugar companies in Western Kenya.

\section{Theoretical Review}

\section{Porter's Diamond Theory}

The model is an economical one developed by Porter (1990). Porter analyzed for four years, ten countries with important share in international commerce (Denmark, Germany, Italy, Japan, South Korea, Singapore, Sweden, Switzerland, Great Britain and USA), establishing the system of the determinants which determine the obtaining of the competitive advantage. Porter's model takes the industry structure (outside - in) as its starting point. This model consists of four national determinants of competitive advantage: factor conditions (human resources, material resources, knowledge resources, capital resources, and infrastructure), demand conditions (home demand for products and services produced in a country), related and supporting industries (existence or non-existence of internationally competitive supplying industries and supporting industries) and firm's strategy, 
INTERNATIONAL JOURNAL OF ACADEMIC RESEARCH IN BUSINESS AND SOCIAL SCIENCES Vol. 9, No. 5, May, 2019, E-ISSN: 2222-6990 @ 2019 HRMARS

structure and rivalry (conditions in a country that determine how companies are established, organized and managed, and that determine the characteristics of domestic competition). Porter's theory is that these factors interact with each other to form conditions where innovation and competitiveness occurs. This explains the existence of so-called low cost- countries (low costs of labour) (Porter, 1990).

\section{Human Capital Theory}

"Human capital" can be defined as knowledge, skills, attitudes, aptitudes, and other acquired traits contributing to production (Goode, 1959). Smith (1776), Sidgwick (1901), Say (1821), Mill (1909) and Roscher (1878) as cited by Kiker (1966), were the early contributors to the literature on human capital economics as an investment which generates a return. Human capital theory was initially developed by Becker (1964). According to this theory, a more educated/skilled workforce makes it easier for a firm to adopt and implement new technologies, thus reinforcing returns on education and training. Empirical studies by Barro (1991), Baumol, Blackman, and Wolf (1989) and Mankiw, Romer, and Well (1992) provide evidence supporting the aggregate effects of education and training. Melike, Melda, Seckin and Elcin (2005) have criticized human capital theory from three different points of view in time. One of the criticisms is that the theory is difficult to be tested, quality of education is not considered and those who take investment decisions cannot calculate its possible rates of return. Another point criticized is the problem of skills. Finally, another criticism of the theory is the dual job market in the context that education will not be sufficient in eliminating income inequality.

\section{Resource Based View Theory}

The origins of the Resource-based view theory (RBV) can be traced back to earlier works by Penrose (1959). She suggested that these resources may only contribute to a firm's competitive position to the extent that they are exploited in such a manner that their potentially valuable services are made available to the firm. A central premise of the resource-based view is that firms compete on the basis of their resources and capabilities. The RBV has emerged in recent years as a popular theory of competitive advantage (Barney, 1991; Wernerfelt, 1989). Newbert (2007) indicates that in 2001, Barney and Arikan published an assessment of 166 empirical articles that tested the RBV in one form or another. Newbert further states that the authors concluded from this study that of these 166 studies, only four (2\%) results were at least partially inconsistent with RBV logic.

This theory has been criticized from the perspective of modern strategic management, the early (Penrose, 1959) understanding of competitive advantage was missing a dimension in that she didn't address the question of how enterprises develop sustainable superior competitive advantage, but instead implicitly adopted a profit-seeking framework. Second, it is regarded as a static theory because it fails to address the fundamental issue as to how future resources can be created (Barney, 2001a, b). Thirdly, RBV does not account for competitive advantage for enterprises in highly dynamic markets. Notwithstanding, scholars have tested basic tenets of RBV and culminated in consistent results and such criticisms have been regarded as academic (Lahiri, 2013; Schroeder, Bates, \& Junttila, 2002). 


\section{Dynamic Capabilities Theory}

According to Pavlou and Sawy, (2011), the dynamic capabilities view originates from Schumpeter's innovation-based competition where competitive advantage is based on the creative destruction of existing resources and novel recombination into new operational capabilities. The concept of dynamic capabilities (DCs) is also the extension of resource-based view (RBV) for its ability to respond to rapidly technological change (Teece, 2007). Dynamic capabilities have lent value to the RBV arguments as they transform what is essentially a static view into one that can encompass competitive advantage in a dynamic context (Barney, 2001a, b).

Empirical researches suggest that the use of DCs is better under rapidly changing environment (Wu, 2010). Augier and Teece (2009) concluded that dynamic capabilities have a tripartite structure: the capability to sense opportunities; the capacity to seize opportunities and the capacity to manage threats through combination, recombination and reconfiguration of assets inside and outside the enterprise's boundaries.

Conceptual Framework

\begin{tabular}{|l|l|l|}
\hline Human Resource Capability & Competitive Advantage \\
- Training and & development & - Sales/Market share \\
- Leadership & - Profit \\
- Labour & - Production costs \\
& turnover/retention & \\
\end{tabular}

Figure 1: Conceptual Framework

\section{Empirical Literature Review}

\section{Strategic Capabilities}

Johnson, Scholes, and Whittington (2011) define Strategic Capability as the adequacy and suitability of the resources and competences of an organization for it to survive and prosper. According to Day (1994) as cited by Almeida, Lisboa, Augusto, and Batista (2013) capabilities are a complex bundle of skills and accumulated knowledge that enable firms to coordinate activities and make use of their assets to create economic value and sustain competitive advantage. Resources are the assets that organizations have, and competencies are the ways those assets are deployed effectively, that is, 'what the organization does well' (Johnson, Scholes, \& Whittington, 2011). The dependence of assets, capabilities, competencies and competitive advantage are as follows:

Resources $\rightarrow$ Competencies $\rightarrow$ Capabilities $\rightarrow$ Competitive Advantage 
INTERNATIONAL JOURNAL OF ACADEMIC RESEARCH IN BUSINESS AND SOCIAL SCIENCES Vol. 9, No. 5, May, 2019, E-ISSN: 2222-6990 ㄷ 2019 HRMARS

\section{Human Resource Capability}

The human resource capability of an organization consists of reliable access to the required people (quantity) with the skills, abilities, attributes and competencies (quality) that the organization needs to meet its purpose and deliver its outputs, in accordance with its strategic goals (State Services Commission, 1999). Hiring competent employees and developing those competencies through effective human resource practices, underpins organizational capability (Ulrich \& Lake, 1991). Theorists focus on the need to develop a pool of human capital that has either higher levels of skills or achieving a better alignment between the skills represented in the firm and those required by its strategic intent (Wricht, Dunford, \& Snell, 2001

Human resources are one of the most valuable resources of an organization and indeed an organization is nothing without human resources (Wesonga, Kombo, Murumba, \& Makworo, 2011). Collins (2009) avers that no company can consistently grow revenues faster than its ability to get enough of the right people to implement that growth and still become a great company. Park, Gardner, and Wright (2004) noted that consistent utilization of HR capabilities is the most consistent step toward developing and maintaining competitive advantage. According to Bontis and Serenko (2007) employee capabilities depend on their training and development as well as job satisfaction levels.

\section{Human Resource Capability and Competitive Advantage of Sugar Companies}

Nguyen, Neck, and Nguyen (2009) researched on the relationship between Knowledge Management (KM) and Sustaining Organizational Competitive Advantage basing on Resource based theory. Three main constructs were technical knowledge management capability, social knowledge management capability and competitive advantage (CA) and were measured using seven-point Likert type scales. Multiple linear regression analysis was performed, and the findings showed that cultural and technological KM dimensions made a unique statistically significant contribution to a firm's CA. Zoubi (2012) found out that leadership competences had a statistically significant impact on competitive advantage. Data was collected through a five-point weighted Likert questionnaire and analyzed. Descriptive analysis frequencies, means and standard deviation were calculated while one-way ANOVA was used to test the hypothesis, and finally simple regression analysis was calculated to assess the impact of leadership competences on competitive advantage in the JTI.

Kahreh, Ahmadi, and Hashemi (2011) established that internal processes largely rely on how capabilities are harnessed for competitive advantage. Data was gathered from 55 academicians and experts in the field of financial services by means of a questionnaire. Statistical analysis showed that empowering employees is positively affected on the three main dimensions of competitive advantage (responsiveness, innovation, and efficiency) for the organizations in the financial services sector in Iran. In the Kenyan context, Bula (2012) found out that labour turnover impacted negatively on the sugar firms. A sample of three sugar firms was used and 120 questionnaires were distributed with a responds rate of $94.17 \%$. Mutunga, Minja, and Gachanja (2014) found out that Executive and Management competencies at innovation are critical success factors in food and beverage companies in Kenya. The population of the study consisted of 138 food and beverage manufacturing firms in Kenya registered with the Kenya Association of Manufacturers (KAM) by 2011 from which 95 companies located in Nairobi, Mombasa and their environs were chosen as the sample. 


\section{Research Gaps}

Literature review on influence of human resource capability on competitive advantage came up with Knowledge management (KM) and sustaining Organizational competitive advantage (Nguyen et al. ,2009); leadership competences on competitive advantage (Zoubi, 2012); Achieving competitive advantage through empowering employees (Kahreh et al. , 2011); influence of Labour turnover in the Sugar Industry in Kenya (Bula, 2012) and innovative adaptation and operational efficiency on sustainable competitive advantage (Mutunga et al. , 2014). Each of these studies looked at only one aspect of constructs contributing towards human resource capability. From the review of literature, it can be seen that not much work has been done on the influence of human resource capability. Gaps have emerged from the empirical studies and this research addresses some of these gaps.

\section{Research Methodology}

The study adopted a descriptive cross section and correlation designs and used a purposive sampling, at the institutional level to obtain the empirical data. This design was used because it allows statistical inferences to broader population (Nachmias \& Nachmias, 2005).The target population of this study was the sugar companies in Kenya. The sample consisted of six sugar companies namely: Muhoroni, Chemelil, Mumias, Nzoia, South Nyanza and West Kenya and the respondents were 727 senior and middle level managers working in these companies. The respondents were 88 drawn from 727 senior and middle level managers working in the six sugar companies Yamane (1967) provides a simplified formula for calculating the sample size of the respondents. A 95\% confidence level and precision level, $e= \pm 10 \%$ is assumed for the equation as follows:

$$
\mathrm{n}=\quad \frac{N}{1+N\left(e^{2}\right)}=\frac{727}{1+727\left(0.1^{2}\right)}=88
$$

Where $\mathrm{n}$ is the sample size and $\mathrm{N}$ is the respondents' size.

Sampling proportionate to size was undertaken to come up with the total number of middle and senior-level managers in each company. Out of the 88 respondents, 22 were senior managers while 66 were middle level managers. Convenience sampling was used during data collection from the respondents. The instrument for primary data collection was a numerical 5-point Likert scale questionnaire pretested for reliability and validity. Secondary data was collected using secondary data collection form and was obtained from the relevant documents of the firms, Kenya Sugar Board and AFFA Year Book of Sugar Statistics. Quantitative data was collected to offer an opportunity to probe, further, into the research issues. The questionnaires were administered by the researcher to the respondents in Muhoroni, Chemelil, Mumias, Nzoia, South Nyanza and West Kenya sugar companies.

Descriptive statistics was used to summarize both the primary and the secondary data to enable meaningful interpretation and description. The descriptive analysis techniques that were used in this study were: percentages, means, overall mean and standard deviation. Baggaley and Hull (1983), Maurer and Pierce (1998), Allen and Seaman (1997) and Vickers (1999) as cited by Brown (2011) have argued that Likert scales can indeed be analyzed effectively as interval scales. Inferential statistics was used in the study to enable the researcher to reach conclusions about the relationship between the variables. Logit regression was used to help answer the objective and find out if the research could be generalized from the sample to the population. Correlation analysis was performed to 
INTERNATIONAL JOURNAL OF ACADEMIC RESEARCH IN BUSINESS AND SOCIAL SCIENCES Vol. 9, No. 5, May, 2019, E-ISSN: 2222-6990 @ 2019 HRMARS

determine if variables were correlated and further to determine the strength and the direction of the relationship between the variables. The correlation strengths were interpreted using Cohen (1988) decision rules Chi-square statistic was used for hypothesis testing to determine the relationships and predictions between the independent and dependent variables. The hypotheses were tested within 95 per cent level of confidence interval or 5 per cent level of significance. The Chi-Square statistic test was also used for the fit of the model

\section{Study Findings}

\section{Bio-data of the respondents}

The Bio-Data indicates that the human resource in the sugar company is up to the task as shown by the bio-data. The sugar sector has youthful staff equipped with adequate knowledge, experience and education to manage the sugar industry. The sector also has very experienced staff that has several years to work for the company before retirement. If, the performance of the sugar industry is poor; then it is due to other factors.

Table 1: Bio Data of the Respondents

\begin{tabular}{|c|c|c|c|}
\hline Variable & Category & Frequency & Percentage (\%) \\
\hline \multirow{2}{*}{ Management level } & Senior Management & 47 & 73.4 \\
\hline & Middle Management & 17 & 26.6 \\
\hline Total & & 64 & 100 \\
\hline \multirow[t]{5}{*}{ Age bracket } & Above 50 years & 10 & 15.6 \\
\hline & $41-50$ years & 21 & 32.8 \\
\hline & $31-40$ years & 21 & 32.8 \\
\hline & $21-30$ years & 11 & 17.2 \\
\hline & Under 21 & 1 & 1.6 \\
\hline Total & & 64 & 100 \\
\hline \multirow{6}{*}{$\begin{array}{l}\text { Highest level of } \\
\text { education }\end{array}$} & PHD Degree & 0 & 0.0 \\
\hline & Master's Degree & 22 & 34.4 \\
\hline & Bachelor's Degree & 29 & 45.3 \\
\hline & Diploma & 13 & 20.3 \\
\hline & Secondary Certificate & 0 & 0.0 \\
\hline & Primary certificate & 0 & 0.0 \\
\hline Total & & 64 & 100 \\
\hline \multirow{5}{*}{$\begin{array}{l}\text { Length of service in } \\
\text { the Organization }\end{array}$} & Above 20 years & 13 & 20.3 \\
\hline & $16-20$ years & 11 & 17.2 \\
\hline & $11-15$ years & 8 & 12.5 \\
\hline & 6-10 years & 11 & 17.2 \\
\hline & 5 years and below & 21 & 32.8 \\
\hline
\end{tabular}


INTERNATIONAL JOURNAL OF ACADEMIC RESEARCH IN BUSINESS AND SOCIAL SCIENCES Vol. 9, No. 5, May, 2019, E-ISSN: 2222-6990 @ 2019 HRMARS

\begin{tabular}{lll}
\hline Total & 64 & 100 \\
\hline
\end{tabular}

\section{Descriptive Statistics}

The study examined human resource capability indicators which were training and development of staff, company leadership and labour turnover in regard to how they influenced the competitive advantage of the sugar companies in Western Kenya. The research results are shown in Table 2 to Table 7 using a Likert scale of 1-5 where 5= Strongly Agree; 4=Agree; 3=Neutral; 2= Disagree; $1=$ Strongly disagree

Table 2: Training and Development

\begin{tabular}{|c|c|c|c|c|c|c|c|c|}
\hline S/N Statement & & 5 & 4 & 3 & 2 & 1 & $M$ & SD \\
\hline $\begin{array}{l}\text { Training needs of employees are } \\
\text { assessed on the basis of their } \\
\text { performance appraisal. }\end{array}$ & $\%$ & 15.6 & 31.3 & 12.5 & 25.0 & 15.6 & 3.06 & 1.36 \\
\hline $\begin{array}{lr}\text { Intrapreneurship } & \text { and } \\
\text { entrepreneurship } & \text { training } \\
\text { approach is used. } & \end{array}$ & $\%$ & 6.3 & 29.7 & 14.1 & 25 & 25 & 2.67 & 1.33 \\
\hline $\begin{array}{l}\text { Performance Appraisal needs } \\
\text { training approach is used. } \\
\text { Strategic Plan needs training }\end{array}$ & $\%$ & 20.3 & 42.2 & 7.8 & 21.9 & 7.8 & 3.45 & 1.26 \\
\hline $\begin{array}{l}\text { approach is used. } \\
\text { Management trainee and }\end{array}$ & $\%$ & 18.8 & 45.3 & 12.5 & 17.2 & 6.2 & 3.53 & 1.17 \\
\hline $\begin{array}{l}\text { Apprenticeship training approach } \\
\text { is used. } \\
\text { Ad Hoc training method is used. }\end{array}$ & $\%$ & 20.3 & 54.7 & 4.7 & 14.1 & 6.3 & 3.69 & 1.14 \\
\hline Coaching and mentoring training & $\%$ & 12.5 & 42.2 & 23.4 & 15.6 & 6.3 & 3.39 & 1.10 \\
\hline approach is used. & $\%$ & 20.3 & 28.1 & 15.6 & 28.1 & 7.8 & 3.25 & 1.29 \\
\hline Overall mean & & & & & & & 3.29 & 1.23 \\
\hline
\end{tabular}

From table 2, the most favored staff training, and development method used in the sugar industries under study was the management trainee and apprenticeship training. The second most used method for manpower training and development within the firms was the strategic plan training approach. 
INTERNATIONAL JOURNAL OF ACADEMIC RESEARCH IN BUSINESS AND SOCIAL SCIENCES

Vol. 9, No. 5, May, 2019, E-ISSN: 2222-6990 @ 2019 HRMARS

Table 3: Company Leadership

\begin{tabular}{|c|c|c|c|c|c|c|c|c|c|}
\hline $\mathrm{S} / \mathrm{N}$ & Statement & & 5 & 4 & 3 & 2 & 1 & $M$ & SD \\
\hline h) & $\begin{array}{l}\text { I am empowered to make } \\
\text { decisions that ensure optimal } \\
\text { performance of my job. }\end{array}$ & $\%$ & 28.1 & 57.8 & 4.7 & 1.6 & 7.8 & 3.96 & 1.05 \\
\hline i) & $\begin{array}{l}\text { Our organization promotes } \\
\text { feedback from employees. }\end{array}$ & $\%$ & 26.6 & 45.3 & 9.4 & 10.9 & 7.8 & 3.71 & 1.20 \\
\hline j) & $\begin{array}{l}\text { My manager is able to } \\
\text { influence others to commit to } \\
\text { his/her vision. }\end{array}$ & $\%$ & 43.8 & 48.4 & 6.3 & 0 & 1.6 & 4.33 & 0.74 \\
\hline k) & $\begin{array}{l}\text { My manager encourages } \\
\text { innovative thinking. }\end{array}$ & $\%$ & 40.6 & 39.1 & 15.6 & 3.1 & 1.6 & 4.14 & 0.90 \\
\hline l) & $\begin{array}{l}\text { My manager recognizes good } \\
\text { performance. }\end{array}$ & $\%$ & 40.6 & 37.5 & 15.6 & 1.6 & 4.7 & 4.08 & 1.00 \\
\hline m) & $\begin{array}{l}\text { Managers and employees of } \\
\text { our firm have relevant } \\
\text { experience in their jobs. }\end{array}$ & $\%$ & 40.6 & 42.2 & 10.9 & 3.1 & 3.1 & 4.14 & 0.96 \\
\hline n) & $\begin{array}{l}\text { My manager has a clear } \\
\text { understanding of the company } \\
\text { and functional goals. }\end{array}$ & $\%$ & 57.8 & 34.4 & 6.3 & 0 & 1.6 & 4.47 & 0.76 \\
\hline o) & $\begin{array}{l}\text { The Chief Executive Officer } \\
\text { (CEO) provides enabling } \\
\text { leadership. }\end{array}$ & $\%$ & 37.5 & 31.3 & 21.9 & 6.3 & 3.1 & 3.94 & 1.07 \\
\hline & Overall mean & & & & & & & 4.10 & 0.96 \\
\hline
\end{tabular}

Table 3 provides the results for the study on leadership and competitive advantage. Leadership overall mean of 4.10 point to the fact that leadership in the organizations to a large extend provided conducive and enabling environment for the operations of the sugar industries under study and standard deviation of 0.96 indicated that there was moderate convergence of respondents on leadership. On all aspects of leadership in the questionnaire the Likert item mean scores were high. 
INTERNATIONAL JOURNAL OF ACADEMIC RESEARCH IN BUSINESS AND SOCIAL SCIENCES

Vol. 9, No. 5, May, 2019, E-ISSN: 2222-6990 @ 2019 HRMARS

Table 4: Labour Turnover

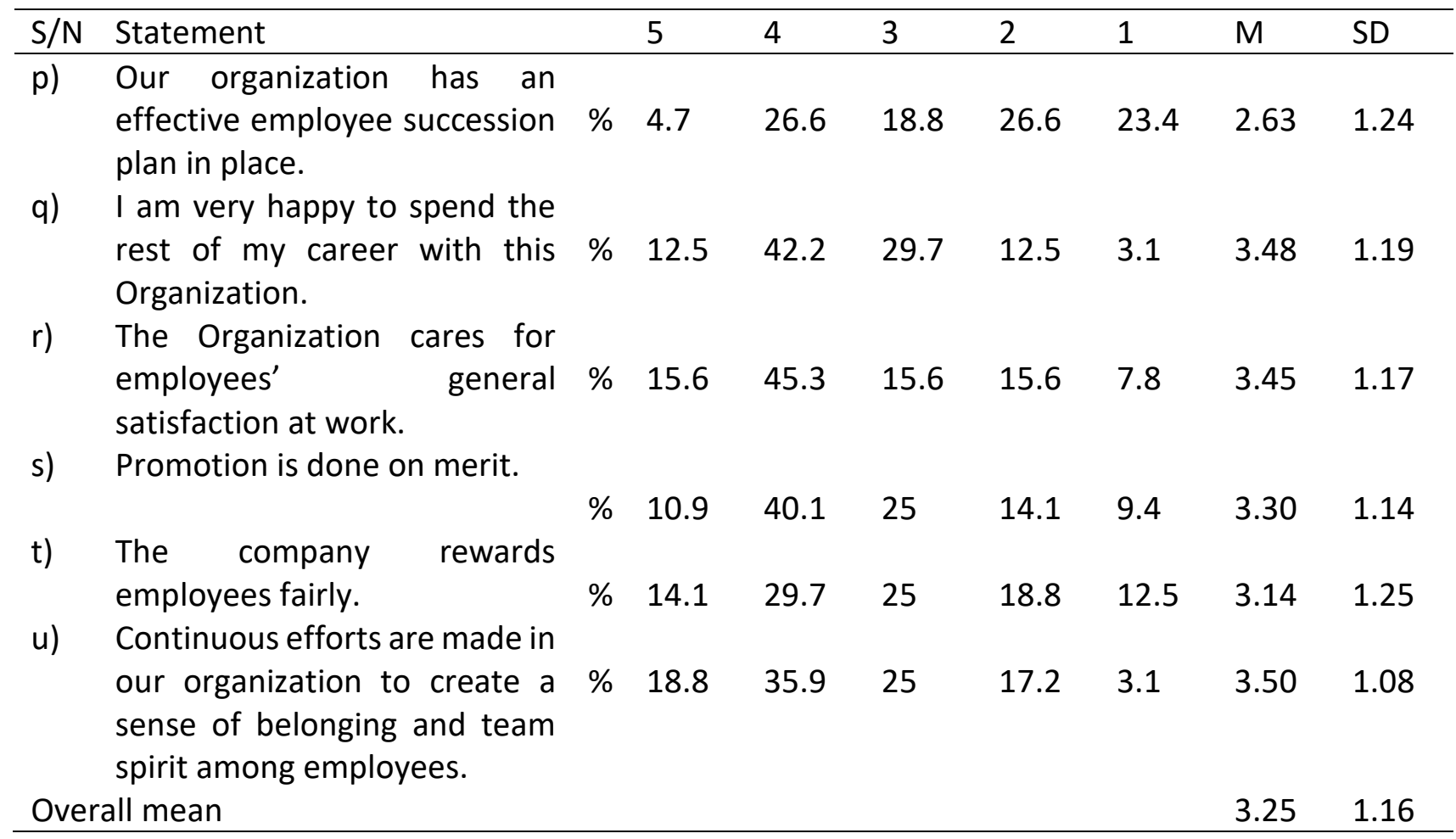

For labour turnover only three Likert item means were 3.45 and above. The human resource capability had an average mean of 3.59 and standard deviation of 1.11 . These were obtained by adding means and standard deviation for questions in Tables 1 to 3 and dividing by the total number of questions respectively. The mean shows that the sugar industry has invested to a large extend in human resource capability.

Table 5: Cadre of Staff most Trained by the Organization

\begin{tabular}{llllll}
\hline & Senior level managers & $\begin{array}{l}\text { middle level } \\
\text { managers }\end{array}$ & $\begin{array}{l}\text { Lower level } \\
\text { managers }\end{array}$ & Union staff & All staff \\
\hline$\%$ & 18.8 & 14.1 & 1.6 & 1.6 & 64.1 \\
\hline
\end{tabular}

From Table 5, $64.1 \%$ of the managers believed that the trainings in their firms targeted every employee; this is in line with Papulova and Papulova (2006) that decisions by managers have a strategic impact and contribute to strategic change. 
INTERNATIONAL JOURNAL OF ACADEMIC RESEARCH IN BUSINESS AND SOCIAL SCIENCES

Vol. 9, No. 5, May, 2019, E-ISSN: 2222-6990 @ 2019 HRMARS

Table 6: Common Training Upgrade Course carried out by the Organization

\begin{tabular}{|c|c|c|c|c|c|c|}
\hline & $\begin{array}{l}\text { Technical } \\
\text { Skills upgrade }\end{array}$ & $\begin{array}{l}\text { Social/ } \\
\text { soft } \\
\text { upgrade }\end{array}$ & skills & $\begin{array}{l}\text { problem solving } \\
\text { skills upgrade }\end{array}$ & $\begin{array}{l}\text { Managerial } \\
\text { Skills upgrade }\end{array}$ & $\begin{array}{l}\text { Conceptual } \\
\text { skills upgrade }\end{array}$ \\
\hline$\%$ & 18.8 & 15.6 & & 10.9 & 40.6 & 9 \\
\hline
\end{tabular}

Table 5 shows that $40.6 \%$ of the respondents were of the view that most training in their organization targeted the development of managerial skills as opposed to $18.8 \%$ of the respondents who felt that trainings in the organization were geared towards the development of technical skills. Lack of emphasizing training of staff on technical skills is likely to lead to depletion or reduction of technical skills in the organization which are critical to achieving the competitive advantage.

Table 7: Cadre of Staff who mostly resign from the Organization

\begin{tabular}{|c|c|c|c|c|c|c|c|}
\hline & $\begin{array}{l}\text { Senior } \\
\text { managers }\end{array}$ & level & $\begin{array}{l}\text { middle level } \\
\text { managers }\end{array}$ & $\begin{array}{l}\text { Lower } \\
\text { managers }\end{array}$ & level & Union staff & All staff \\
\hline$\%$ & 25 & & 43.8 & 15.6 & & 0 & 15.6 \\
\hline
\end{tabular}

From Table 4, the overall mean Likert scale for labour turnover was 3.25. This indicated possibility of employees leaving the organizations. The respondents felt that it was unlikely or rare for the union staff to resign as exhibited by the nil score.

The study used secondary data on resignations of employees and the length of service of the respondents in their present companies to verify this perception that senior and middle level manager were likely to leave the organizations. The information was provided by the companies and is tabulated in Table 7

Table 8: Employees Resignations Records from 2011 to 2015

\begin{tabular}{llllllll}
\hline Company & & 2011 & 2012 & 2013 & 2014 & 2015 & $\begin{array}{l}\text { Total } \\
\text { resignations }\end{array}$ \\
\hline Muhoroni Sugar & Resignations & 6 & 10 & 7 & 6 & 0 & 29 \\
Chemelil & Resignations & 10 & 16 & 12 & 6 & 2 & 46 \\
West Kenya & Resignations & 5 & 11 & 10 & 8 & 10 & 44 \\
Nzoia & Resignations & 3 & 4 & 20 & 9 & 6 & 42 \\
South Nyanza & Resignations & 8 & 8 & 10 & 20 & 10 & 56 \\
Mumias & Resignations & 11 & 10 & 0 & 19 & 50 & 90 \\
\hline
\end{tabular}

Source: Respective Sugar companies (2016)

From the secondary data obtained from the companies, staff across all levels who resigned from 2011 to 2015 were; Muhoroni Sugar Company were 29, Chemelil Sugar Company were 46, West Kenya Sugar Company were 44, Nzoia Sugar Company were 42, South Nyanza Sugar Factory were 56 and Mumias Sugar Company had 90 employees. These figures exclude those who retired, were terminated for various offences or died. Senior and middle level managers in the firms in 2016 were: Muhoroni 64, Chemelil 67, West Kenya 30, Nzoia 226, South Nyanza 140 and Mumias 200. 
From the primary data, $68.8 \%$ of the respondents felt that senior and middle level managers in the organizations were prone to resignations. If this view was held true, then $68.8 \%$ of all resignations each year would be attributed to senior and middle level managers. This meant that in the last five years the total number of senior and middle level managers who had resigned would be; Muhoroni 20 against staff strength of 64, Chemelil 32 managers against the establishment of 67, West Kenya 30 managers against 30 positions, Nzoia 29 resignations of middle and senior managers against 226 positions, South Nyanza 39 managers against 140 and finally Mumias 62 managers against 200 managers. This result was supported by the demographic data from Table 1 where $32.8 \%$ of the respondents' length of service in the Organization was less than five years. This high labour turnover amongst middle and senior managers destabilizes the smooth running of the institutions and is detrimental to the experience required to facilitate continuous, efficient and effective running of the sugar industry in the long run.

\section{Correlation Analysis}

Table 10: Correlation of Human Resource Capability and Competitive Advantage

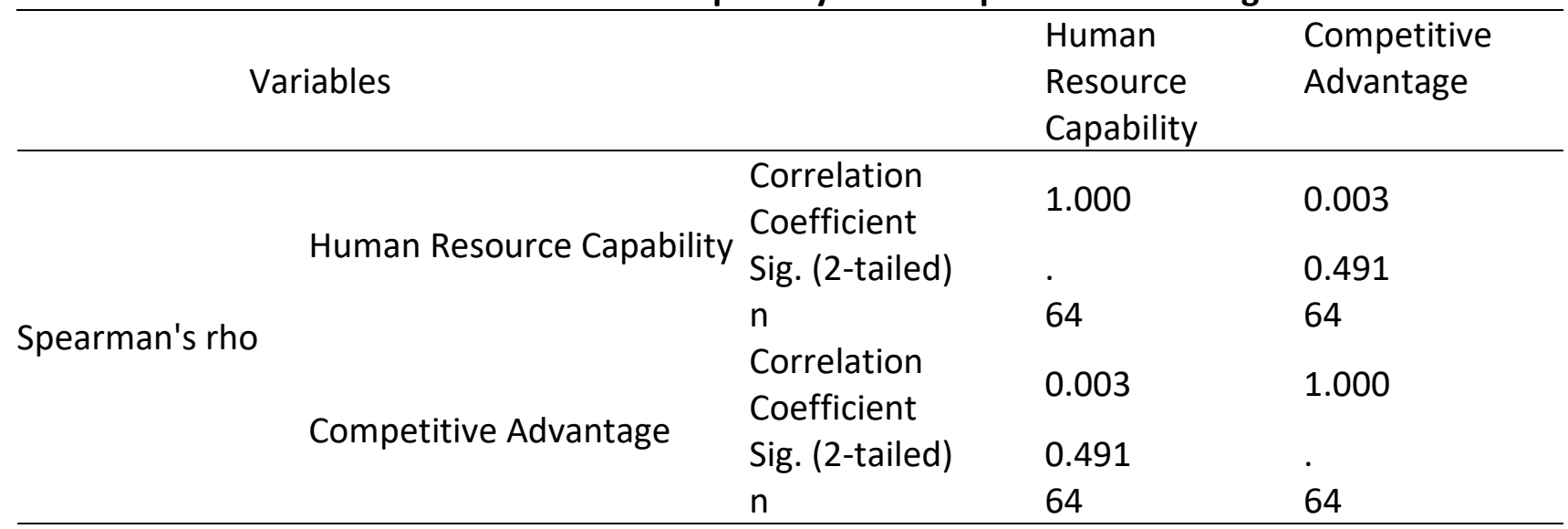

It was established that there was a statistically insignificant weak positive correlation between human resource capability and competitive advantage; $r=0.003, p=0.491, C L=95 \%$ (2-tailed). This shows that the competitive advantage of the sugar companies in Western Kenya is positively influenced by the human resource capability.

\section{Hypothesis Testing}

H01: There is no statistically significant relationship between human resource capability and competitive advantage of sugar companies in Western Kenya.

The $\mathrm{X} 2$ test statistic $=0.001 \mathrm{df}=1$

The $\mathrm{X} 2$ critical values from the Tables $=3.84$ at $95 \% \mathrm{CL}$

Since the $X 2$ critical values $=3.84>X 2$ test statistics $=0.001(\mathrm{df}=1)$, it doesn't fall in the rejection region. We therefore fail to reject the null hypothesis and conclude that there is no sufficient evidence to support a statistically significant difference in the relationship between human resource capability and competitive advantage of sugar companies in Western Kenya. 
INTERNATIONAL JOURNAL OF ACADEMIC RESEARCH IN BUSINESS AND SOCIAL SCIENCES

Vol. 9, No. 5, May, 2019, E-ISSN: 2222-6990 @ 2019 HRMARS

\section{Logit Regression Analysis}

Table 9: Logit of Human Resource Capability and Competitive Advantage

\begin{tabular}{|c|c|c|c|c|c|c|c|c|}
\hline \multirow{2}{*}{\multicolumn{2}{|c|}{$B$}} & \multirow[t]{2}{*}{ S.E. } & \multirow[t]{2}{*}{ Wald } & \multirow[t]{2}{*}{$d f$} & \multirow[t]{2}{*}{ Sig. } & \multirow[t]{2}{*}{$\operatorname{Exp}(B)$} & \multicolumn{2}{|c|}{ 95\% C.L.for $\operatorname{EXP}(B)$} \\
\hline & & & & & & & Lower & Upper \\
\hline Human R & y0.012 & 0.502 & 0.001 & 1 & 0.981 & 1.012 & 0.378 & 2.709 \\
\hline Constant & -0.194 & 0.361 & 0.289 & 1 & 0.591 & 0.824 & & \\
\hline
\end{tabular}

Odds of competitive advantage of sugar companies $=-0.194+0.012 x_{1}+0.863$, Where

$\beta_{0}=-0.194$ is the constant

$x_{1}$ - Human resource capability

0.863 is the error term (SE)

The logit results revealed that companies that had strong human resource capability were 1.012 times more likely to enjoy competitive advantage compared to those that had a weak human resource capability, however, this relationship was statistically insignificant $(p=0.981)$. This leads to a conclusion that the influence of the human resource capability on the competitive advantage of the sugar companies under study depends to a large extent on how human resource is deployed rather than the availability of the human resources.

\section{Summary of Findings}

The study established that training and development of employees was given moderate consideration in the sugar firms. Most training in the organizations target the development of managerial skills as opposed to the development of technical skills. Lack of training of staff on technical skills is likely to lead to depletion or reduction of technical skills in the organization which are critical to achieving the competitive advantage. The sugar firms under study are expected not to perform very well and enjoy competitive advantage due to limited investment in training and development of their employees in technical fields. Leadership in the organizations to a large extend provided conducive and enabling environment for the operations of the sugar industries. Employee retention issues were being implemented moderately in the sugar companies with the end result of creating some level of employee dissatisfaction. Demographic data indicated high labour turnover among the middle and senior level managers. This is detrimental to the smooth continuity of business in the sugar industry and its competitive advantage. Employees are the backbone of any business success and therefore, they need to be motivated and maintained in the organization if the firms have to enjoy competitive advantage.

The outcome of logit regression analysis was that there was a positive relationship between the human resource capability and competitive advantage; however, this relationship was statistically insignificant. Correlation analysis established that there was a statistically insignificant weak positive correlation between human resource capability and competitive advantage. Hypothesis testing established that there was no sufficient evidence to support a statistically significant difference in the relationship between human resource capability and competitive advantage of sugar companies in Western Kenya. Hence, the null hypothesis was accepted. 
INTERNATIONAL JOURNAL OF ACADEMIC RESEARCH IN BUSINESS AND SOCIAL SCIENCES Vol. 9, No. 5, May, 2019, E-ISSN: 2222-6990 @ 2019 HRMARS

\section{Conclusions}

The relationship between human resource capability and competitive advantage of sugar companies in Western Kenya is not statistically significant as indicated by the weak correlation and logit analyses results and by the hypothesis results. This research contributes to the understanding of the critical factors affecting the competitive advantage of sugar companies in Kenya in comparison to other COMESA sugar growing countries. The research opens up areas for further research on strategic factors affecting the sugar industry in Kenya and by extension the COMESA region. The study is important to the sugar companies' managers and the government of Kenya in understanding and addressing some of the perennial problems facing the sugar industry in Kenya. The research contributes to the body of knowledge in the Kenyan sugar sector and awakens the managers and the government of Kenya in reevaluating the factors critical to the performance of the sugar industry.

Companies that had strong human resource capability were more likely to enjoy competitive advantage compared to those that had weak human resource capability. Competitive advantage of the sugar companies in Western Kenya is positively influenced by the human resource capability.

\section{Recommendations}

The industry should pay keen attention on how human resource capabilities are placed and utilized. If observed, the result is likely to lead to better performance of the sector. The Bio-Data indicates that the human resource in the sugar companies is up to the task. The sugar sector has both youthful staff equipped with adequate knowledge and education, and mature experience staff to lead the sugar industry to success. The sector also has very experienced staff that has several years to work for the company before retirement. Yet, the sugar sector in Kenya is not competitive in comparison to other COMESA sugar producing countries. If, the performance of the sugar industry is poor; then it is due to other factors. If these other factors are not addressed; then the sugar sector in Kenya will remain a drain on the Ex - Chequer draining useful resources which would otherwise be used for the development of the nation.

\section{References}

Almeida, F. E. B., Lisboa, J. V., Augusto, M. G., \& Batista, P. C. S. (2013). Organizational capabilities, strategic orientation, strategy formulation quality, strategy Implementation and organizational performance in Brazilian Textile Industries. EnANPAD XXXVII, 1 - 15.

Argote, L., \& Ingram, P. (2000). Knowledge Transfer: A Basis for Competitive Advantage in Firms. Organizational Behavior and Human Decision Processes, 82(1), 150-169.

Augier, M., \& Teece, D. J. (2009). Dynamic capabilities and the role of retailers in business strategy and economic competitive advantage. Organization Science, 20(2), 410-421.

Barney, J. B. (1991). Firm resources and sustained competitive advantage. Journal of Management, 17(1), 99-120.

Barney, J. B. (2001a). Is the resource-based "view" a useful perspective for strategic management research? Yes. Academy of Management Review, 26, 41-56.

Barney, J. B. (2001b). "Resource-based theories of competitive advantage: a ten-year retrospective on the resource-based view". Journal of Management, 27, 643-650. 
INTERNATIONAL JOURNAL OF ACADEMIC RESEARCH IN BUSINESS AND SOCIAL SCIENCES Vol. 9, No. 5, May, 2019, E-ISSN: 2222-6990 @ 2019 HRMARS

Barro, R. J. (1991). Economic growth in a cross section of countries. Quarterly Journal of Economics, 106, 407-443.

Batool, A., \& Batool, B. (2012). Effects of employees training on the organizational competitive advantage: Empirical study of Private Sector of Islamabad, Pakistan. Far East Journal of Psychology and Business, 6(1), $59-72$.

Becker, D. (1964). Human capital. A theoretical and empirical analysis with special reference to education. New York: Columbia University Press.

Bontis, N., \& Serenko, A. (2007). The moderating role of human capital management practices on employee capabilities. Journal of Knowledge Management 11(3), 31 - 51.

Brown, J. D. (2011). Likert items and scales of measurement? SHIKEN: JALT Testing \& Evaluation SIG Newsletter, 15(1) 10-14.

Bula, H. O. (2012). Labor turnover in the sugar industry in Kenya. European Journal of Business and Management, 4(9), $111-119$.

Chuang, H. M., Liu, M. J., \& Chen, Y. S. (2014). The Effects of Human Resource Capability and Internal Customer Satisfaction on Organizational Effectiveness. International Journal of Distributed Sensor Networks, Article ID 835194, 1 - 10.

Cohen, J. (1988). Statistical power analysis for the behavioral sciences (2nd edition). New Jersey State: Lawrence Erlbaum.

Duncan, W. J., Gintei, P. M., \& Swayne L. E. (1998). Competitive advantage and internal organizational assessment. Academy al Managemsnl Executive, 12 (3), 6- 16.

Edralin, D. M. (2004). Training: A Strategic HRM Function. Notes on Business Education 7 (4). Published_by the De La Salle University, College of Business and Economics Research and Development_(CBERD).

Faugoo, D. (2009). Globalisation and Its Influence on Strategic Human Resource Management, Competitive Advantage and Organisational Success. International Review of Business Research Papers, 5 (4), 123-133.

Johnson, G., Whittington, R., and Scholes, K. (2011). Exploring Strategy (9 ${ }^{\text {th }}$ Edition). Published by Prentice Hall

Kahreh, M. S., Ahmadi, H., \& Hashemi, A. (2011). Achieving competitive advantage through empowering employees: An empirical study. Far East Journal of Psychology and Business, 3(2), $26-37$.

Kaumbutho, P. G., Awiti, L. M., \& Some, D. K. A. (1991). Analysis of sugarcane and sugar production costs for the Kenyan Sugar Industry. Kenya Sugar Authority.

Kenya Sugar Board (KSB). Year Book of Sugar Statistics (2010). Nairobi: KSB

Kenya Sugar Industry (2009). Nairobi, Kenya:.

Kiker, B. F. (1966). The historical roots of the concept of human capital. Journal of Political Economy, 74(5), $481-499$.

Lahiri, P. (2013). Parametric bootstrap in small area estimation: joint program in survey methodology. College Park, USA.

Mankiw, N. G., Romer, D., \& Weil, D. N. (1992). A contribution to the empirics of economic growth. Quarterly Journal of Economics, 107(2), Cambridge: MIT Press Journals, 407-437. 
INTERNATIONAL JOURNAL OF ACADEMIC RESEARCH IN BUSINESS AND SOCIAL SCIENCES Vol. 9, No. 5, May, 2019, E-ISSN: 2222-6990 @ 2019 HRMARS

Melike, B., Melda, O., Seçkin, S., \& Elçin, A. (2005). Determinants of Human Capital Theory, Growth and Brain Drain; An Econometric Analysis for 77 Countries. Applied Econometrics and International Development,5(2), $109-140$.

Moorthy, M. K., Tan, A., Choo, C., Wei, C. S., Ping, J. T. Y., \& Leong, T. K. (2012). A Study on Factors Affecting the Performance of SMEs in Malaysia. International Journal of Academic Research in Business and Social Sciences, 2(4), 224 - 239.

Mutunga, S. L., Minja, D., \& Gachanja, P. (2014). Innovative adaptation and operational efficiency on sustainable competitive advantage of food and beverage firms in Kenya. European Journal of Business and Innovation Research, 2(2), 32-50.

Nachmias, C. F., \& Nachmias, D. (2005). Research methods in the social sciences. London, Arnold, A member of the Hodder Headline Group.

Newbert, S. L. (2007). Empirical research on the resource-based view of the firm: An assessment and suggestions for future research. Strategic Management Journal, 28, 121-146.

Nguyen, Q. T. N., Neck, P. A., \& Nguyen, T. H. (2009). The Critical role of knowledge management in achieving and sustaining organizational competitive advantage. International Business Research, 2(3), 3-16.

Njuguna, R. K., Muathe, S. M., \& Kerre, F. P. (2014). The Moderating effect of industrial context on the relationship between Brand Equity and Consumer Choice in Branded Bottled Water Nairobi, Kenya. European Scientific Journal, 10(4), 337 - 349.

Odek, O., Kegode, P., \& Ochola, S. (2003). The Challenges and way forward for the sugar sub-sector in Kenya. Nairobi, Kenya.

Ongori, H. (June 2007). A review of the literature on employee turnover. African Journal of Business Management, 049 - 054.

Park, H. J., Gardner, T. M., \& Wright, P. M. (2004). HR practices or HR capabilities: Which matters? Insights from the Asia Pacific region. Asia Pacific Journal of Human Resources, 42(3), 260-273.

Pavlou P., \& El Sawy O (2011). Understanding the black box of Dynamic Capabilities. Decision Sciences, 42(1), 239-272.

Penrose, E.T. (1959). The Theory of the Growth of the Firm. New York: Oxford University Press:

Plessis, A. J., Beaver, B., \& Nel, P.S. (2006). Closing the gap between current capabilities and future requirements in Human Resource Management in New Zealand: Some empirical evidence. Journal of Global Business and Technology, 2 (1), $33-47$.

Porta, M. (2008). A dictionary of epidemiology (5th ed.). Oxford: Oxford University Press.

Porter, M. E. (1990, March/April). The Competitive advantage of nations. Harvard Business Review, $73-93$.

Rumelt, R. P., Schendel, D. E., \& Teece, D. J. (1994). Fundamental issues in strategy. In Rumelt, R. P., Schendel, D. E., \& Teece D. J. (eds.), Fundamental Issues in Strategy: A Research Agenda: 953. Boston, MA: Harvard Business School Press.

Schroeder, R. G., Bates, K. A., \& Junttila, M. A. (2002). A resource-based view of manufacturing strategy and the relationship to manufacturing competitive advantage. Strategic Management Journal, 23(2), $105-117$.

State Services Commission Wellington, New Zealand. (1999). Measuring human resource capability in the public service (Occasional Paper No. 13). 
INTERNATIONAL JOURNAL OF ACADEMIC RESEARCH IN BUSINESS AND SOCIAL SCIENCES

Vol. 9, No. 5, May, 2019, E-ISSN: 2222-6990 (C) 2019 HRMARS

Teece, D. J. (2007). Explicating Dynamic Capabilities: The Nature and Micro foundations of (Sustainable) Enterprise Performance. Strategic Management Journal, 28(13), 1319-50.

Ulrich, D., \& Lake, D. (1991). Organizational Capability: creating competitive advantage. Academy of Management Executive, 5(1), 77 - 92.

Wanyande, P. (2001). Management politics in Kenya's Sugar Industry: Towards an effective framework. Afr.j.polit. sci., 6(1), 123-140.

Wernerfelt, B. (1989). From critical resources to corporate strategy. Journal of General Management, 14(3), 4-12.

Wesonga, J., Kombo, A., Murumba, N., \& Makworo, E. (2011). The factors contributing to labour turnover in the sugar industry in Kenya: A case of Sony Sugar Company limited. Educational Research, 2 (5), 1138-1148.

Wright, P. M., McMahan, G. C., \& McWilliams, A. (1993). Human Resource and SustainedCompetitive Advantage: A resource - Based Perspective. Center for Effective Organizations. Marshall School of Business. University of Southern Califonia, Los Angeles.

Wu, L.-Y. (2010). Applicability of the Resource-Based and Dynamic-Capability Views under Environmental Volatility. Journal of Business Research, 63, 27-31.

Yamane, T. (1967). Statistics, an introductory analysis. (2nd. ed.). New York: Harper and Row.

Zoubi, M. R. (2012). Leadership competencies and competitive advantage: "Empirical study on Jordan Telecommunications". European Journal of Business and Management, 4(7), 234 - 247. 